\title{
Aphanizomenon slovenicum sp. nov. : morphological and ecological characters of a new cyanophyte/cyanobacterial species from Lake Bled, Slovenia
}

\author{
S. Rekar ${ }^{1}$ \\ F. Hindák ${ }^{2}$
}

Keywords : Cyanophyta/Cyanobacteria, Aphanizomenon slovenicum, new species, taxonomy, ecology, subalpine lakes, water bloom, Slovenia.

The morphology and ecology of a†new species of the cyanophyte/cyanobacterial genus Aphanizomenon Morren ex Bornet et Flahault, $A$. slovenicum Rekar et Hindák, are described from Lake Bled, NW Slovenia. The species produced a heavy water bloom in May - December 1997 but disappeared during 1998. Macroscopic flakes of bundles of trichomes similar to A. flosaquae (L.) Ralfs ex Bornet et Flahault formed in a layer between $10-20 \mathrm{~m}$ depth. They differed from A. flos-aquae by shorter and narrow short cylindrical to barrel-shaped cells, and by trichomes that sometimes consisted of morphologically different cell sections. Maximum abundance was found in August : 655 trichomes. $\mathrm{ml}^{-1}$. Heterocytes were occasionally present and akinetes have been observed only in laboratory cultures. The main characteristics of the investigated cultures of $A$. slovenicum and $A$. flos-aquae isolated from a fishpond at Ledava (NE Slovenia) are given.

Aphanizomenon slovenicum nov. sp. : morphologie et écologie d'une espèce nouvelle de cyanophyte / cyanobactérie du lac Bled, Slovénie

Mots-clés : Cyanophyta/Cyanobacteria, Aphanizomenon slovenicum, espèce nouvelle, taxonomie, écologie, fleur d¥eau, lacs subalpins, Slovénie.

Une nouvelle espèce, A. slovenicum nov. sp. découverte dans le lac Bled (N.O. Slovénie) est décrite du point de vue morphologique et écologique. Cette espèce a donné naissance de mai à décembre 1997, à une efflorescence sous forme de faisceaux floconneux macroscopiques entre 10 et $20 \mathrm{~m}$ de profondeur ; elle a disparu en 1998 . Elle se différencie de Aphanizomenon flosaquae par des cellules plus courtes et plus étroites, cylindriques à dolioformes ; de plus, des portions de filaments présentent des cellules morphologiquement différentes. Le maximum d'abondance a été recensé en août : 655 filaments.ml-1. Les hétérocystes sont souvent absents et les akinètes ont été observés seulement en laboratoire. A l'aide de cultures, les principales caractéristiques de $A$. slovenicum et $A$. flos-aquae isolées d'un étang de pisciculture à Ledava (N.E. Slovénie), sont précisées.

\section{Introduction}

The genus Aphanizomenon Morren ex Bornet et Flahault 1886 belongs to the family Nostocaceae Eichler, 1829, subfamily Anabaenoideae (Bornet et Flahault)

\footnotetext{
1. The Environmental Agency of the Republic of Slovenia, Monitoring Office, Water quality Section, Limnology department, Kidriceva cesta 10, SLO-4260 Bled, Slovenia.

E-mail : spela.rekar@rzs-hm.si

2. Institute of Botany, Slovak Academy of Sciences, Dúbravská cesta 14, SK-84223 Bratislava, Slovakia.

E-mail : frantisek.hindak@savba.sk
}

Kirchner 1900 (cf. Komárek \& Anagnostidis 1989). The genus is characterized by bundles of trichomes or by solitary trichomes. Trichomes are uniseriate, isopolar and non-branching, with a wide or narrow (sometimes not visible) mucilaginous envelope, and with the ability to produce heterocytes and akinetes. In contrast to the genus Anabaena Bory, the structure of trichomes is subsymmetric, not metameric. The number of heterocytes in the type species, A. flos-aquae (L.) Ralfs ex Bornet et Flahault 1886, is small, from one to a maximum of three, and the heterocytes in trichomes are not regularly symmetrically arranged. Elongate and/or attenuated terminal cells of the trichomes are also cha- 
racteristic for the representatives of the genus Aphanizomenon (cf. Komárek \& Anagnostidis 1989).

This definition of the genus Aphanizomenon has currently been more or less accepted. Taxonomic position of species forming macroscopic bundles (taxa near the type species A. flos-aquae) is clear in contrast to the species with solitary trichomes (Komárek 1958, Horecká \& Komárek 1979, Hindák \& Moustaka 1988, Komárek \& Kovácik 1989, Hindák 1992, 2000, Kling et al. 1994, Komárková-Legnerová \& Mátyás 1995, Komárek 1996).

Only two species of the genus Aphanizomenon displaying macroscopic bundles have been validly described, i.e. the type species A. flos-aquae (cf. Geitler 1930-1932, Huber-Petalozzi 1938, Hollerbach et al. 1953, Starmach 1966, Kondrateva 1968) and A. yezoense M. Watanabe (Watanabe 1991). The third possible species, mentioned by Komárek (1996), is A. klebahnii (Elenkin) Pechar et Kalina in prep. $(=A$. flosaquae var. klebahnii Elenkin 1909) which has not been validly established. While the type species (as well its var. klebahnii) has been frequently recorded from many countries of temperate zone, $A$. yezoense is much less known. It was firstly described under the name Aphanizomenon sp. from some lakes in N. Greece by Anagnostidis et al. (1988) and Hindák \& Moustaka (1988), but later established as an independent species by Watanabe (1991) from Japan. According to Komárek (1996), A. yezoense is probably an invasive species, nowadays found in larger lakes and water reservoirs in many countries, including the Czech Republic. All taxa mentioned above are similar in the shape of the macroscopic bundles but differing from each other by the si$z e$ of trichomes and morphology of the end cells.

In this article the morphology and ecology of the new species of the genus Aphanizomenon, A. slovenicum, are described from the plankton of Lake Bled in Slovenia. The macroscopic bundles of trichomes of the new species appear to be closely related to A. flos- aquae but differed significantly in the shorter and narrower cylindrical to barrel-shaped cells, by the end cells and the intercalary disintegration of trichomes at differentiated vegetative cells. In contrast to the type species, the heterocytes formed only occasionally and the akinetes were only observed in laboratory cultures.

There is little published data on the phytoplankton of Lake Bled. The first algological investigations of Lake Bled were carried out by Hansgirg in 1890 . According to Vrhovsek \& Kosi (1981) 213 different species of cyanophytes and algae were identified from Lake Bled.

\section{Study area}

\subsection{Hydromorphological characteristics}

Lake Bled is a typical dimictic, subalpine lake of glacial-tectonic origin, situated in the NW Slovenia (North latitude $14^{\circ} 7^{\prime}$ and $46^{\circ} 23^{\prime}$ East longitude), Europe (Fig. 1). It occupies an area of $1.4 \mathrm{~km}^{2}$ with a maximum depth $30.1 \mathrm{~m}$ and the average depth $17.9 \mathrm{~m}$ (Rejic \& Sketelj 1962). Some other hydromorphological data are given in Table 1.

\subsection{Macrophytes}

The littoral zone is limited due to the lake origin. Large associations of macrophytes are only situated at the SW part of the lake, and therefore the phytoplankton represents the main driving function for the whole ecosystem.

As part of a monitoring programme, macrophytes from Lake Bled were identified yearly at the beginning and at the end of the vegetation by Bercic-Urbanc (1995). In 1997 (Bercic-Urbanc, Monitoring reports, unpubl.) the following species were presented : Alisma plantago-aquatic L., Acorus calamus L., Caltha palustris L., Carex riparia Curt., Eupatorium cannabinum L., Filipendula ulmaria L., Iris pseudacorus L., Lycopus europaeus L., Lysimachia vulgaris L., Mentha aquatica L., Menyanthes trifoliate L., Phragmites aus-

Table 1. Hydromorphological characteristics of Lake Bled.

Tableau 1. Caractéristiques hydromorphologiques du lac Bled.

\begin{tabular}{ll}
\hline Height above see level & $475 \mathrm{~m}$ \\
Surface area & $1.438 \mathrm{~km}^{2}$ \\
Maximal depth & $30.1 \mathrm{~m}$ \\
Average depth & $17.9 \mathrm{~m}$ \\
Volume & $25.69 \mathrm{mio} . \mathrm{m}^{3}$ \\
Catchment area & $8.1 \mathrm{~km}^{2}$ \\
Theoretical retention time before sanitation & 3.6 years \\
Theoretical retention time in the last 5 years & $\sim 1.5$ years \\
\hline
\end{tabular}




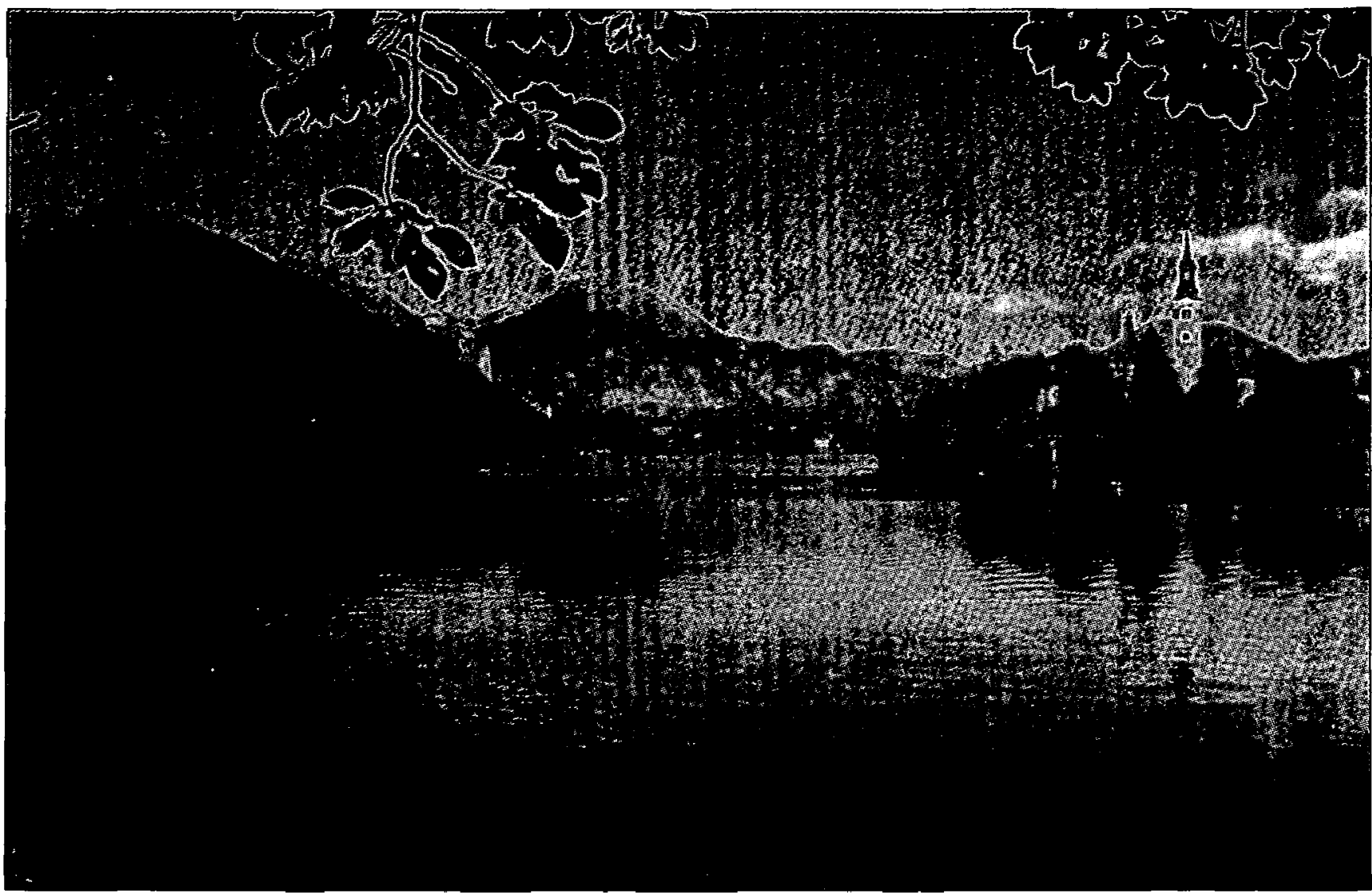

Fig. 1. Lake Bled during the mass development of Aphanizomenon slovenicum in August 1997. Orig. photo.

Fig. 1. Lac Bled lors du maximum de développement de Aphanizomenon slovenicum en août 1997. Orig. photo.

tralis (Cav.) Trin., Schoenoplectus lacustris (L.), Palla f. fluitans, Solanum dulcamara L., Sparganium erectum L., Veronica beccabunga L. ; natans plants : $\mathrm{Nu}$ phar lutea (L.) Sm., Nymphaea alba L.; submersal plants : Batrachium trichophyllum (Chaix.) Bosch, Chara sp., Cladophora sp., Myriophyllum spicatum L., Potamogeton filiformis Pers.

\subsection{Eutrophication and restoration of the lake}

As early as the beginning of the 1950's a permanent cyanophyte water bloom consisting of the species Planktothrix rubescens (DC. ex Gom.) Anagn. et Komárek (syn. Oscillatoria rubescens DC. ex Gom.) indicated a warning signal of the increased eutrophication, high trophic (hypereutrophic) status and disturbance of the natural balance of Lake Bled system. The main cause of the eutrophication was the resort's overloaded and poorly managed sewerage system that was closely linked to the rapid development of massive tourism. The general lack of wind circulation and its poor natural inflow accelerated the speed and intensity of the eutrophication processes. The unpleasant appearance of the lake during the prolongated cyanophyte water blooms resulted in the initiation of a restoration programme including sanitation and other restorative measures. Prior to 1964 only 13 small streams had been feeding the lake with the total inflow smaller than $0.35 \mathrm{~m}^{3} \mathrm{~s}^{-1}$. In order to increase the natural flow of the water and aerate the lake, oxygen rich water from the river Radovna was channelled into the lake in 1964. On the basis of Imboden's model, a deep outlet from the lake, a siphon, was built in 1981 - 1982. In the years 1982 - 1985 renovation of Bled's sewerage system decreased inflow of wastewater into the lake.

Since the siphon installation and sewage system development in 1982, nutrient concentrations have been gradually decreasing. This has been reflected in a lower total phytoplankton biomass, lower average chlorophyll concentration and increased higher average and maximum transparency of the lake.

According to monitoring data (Vrhovsek et al. 1982), Lake Bled ranked among the eutrophic lakes in 1970 's. Owing to its effective anti-pollution treatment, Lake Bled has now joined again the rank of the moderately polluted mesotrophic lakes (Table 2 ).

\section{Material and methods}

The monitoring of Lake Bled has been a part of the Slovene National Water-Quality Monitoring Programme since 1975. Samples for physical, chemical and biological analyses were taken in 1995 - 2000 in the eastern 
Table 2. Some chemical and physical characteristics of Lake Bled compared with of the OECD 1982 lake classification (Anonymous 1987).

Tableau 2. Quelques paramètres physico-chimiques du lac Bled comparés avec ceux de la classification des lacs de l'OECD (1982) (Anonymous 1987).

\begin{tabular}{ccccccc}
\hline Trophic stage & $\begin{array}{c}\text { Total } \\
\text { phosphorus } \\
\text { concentration } \\
\left(\mu \mathrm{g} \mathrm{P.I^{-1 } )}\right.\end{array}$ & $\begin{array}{c}\text { Inorganic } \\
\text { nitrogen } \\
\text { concentration } \\
\left(\mu \mathrm{g} \mathrm{N} . \mathrm{I}^{-1}\right)\end{array}$ & $\begin{array}{c}\text { Average } \\
\text { Secchi } \\
\text { depth } \\
(\mathrm{m})\end{array}$ & $\begin{array}{c}\text { Minimal } \\
\text { Secchi } \\
\text { depth } \\
(\mathrm{m})\end{array}$ & $\begin{array}{c}\text { Average } \\
\text { chlorophyll } a \\
\text { concentration } \\
\left(\mu \mathrm{g} . \mathrm{I}^{-1}\right)\end{array}$ & $\begin{array}{c}\text { Maximal } \\
\text { chlorophyll } a \\
\text { concentration } \\
\left(\mu \mathrm{\mu g} \mathrm{I}^{-1}\right)\end{array}$ \\
\hline u-oligotrophic & $<4$ & $<200$ & $>12$ & $>6$ & $<1$ & $<2.5$ \\
oligotrophic & $<10$ & $200-400$ & $>6$ & $>3$ & $<2.5$ & $<8$ \\
mesotrophic & $10-35$ & $300-650$ & $6-3$ & $3-1.5$ & $2.5-8$ & $8-25$ \\
eutrophic & $35-100$ & $500-1500$ & $3-1.5$ & $1.5-0.7$ & $8-25$ & $25-75$ \\
hypereutrophic & $>100$ & $>1500$ & $<1.5$ & $<0.7$ & $>25$ & $>75$ \\
\hline 1979 & 80.0 & 986 & 4.0 & $<1.0$ & 17.0 & 48.5 \\
1989 & 31.1 & 453 & 4.1 & 1.1 & 8.8 & 28.7 \\
1990 & 25.0 & 431 & 5.0 & 2.0 & 5.6 & 29.6 \\
1994 & 19.3 & 419 & 5.5 & 2.7 & 5.0 & 35.4 \\
1995 & 15.2 & 477 & 5.9 & 2.5 & 3.4 & 17.2 \\
1996 & 14.5 & 455 & 6.5 & 3.8 & 2.8 & 11.2 \\
1997 & 12.7 & 495 & 8.4 & 4.1 & 2.9 & 14.4 \\
1998 & 15.5 & 374 & 5.8 & 2.4 & 7.6 & 29.1 \\
1999 & 17.9 & 312 & 5.0 & 1.2 & 9.3 & 47.4 \\
2000 & 14.3 & 280 & 5.3 & 2.0 & 7.2 & 25.7 \\
\hline
\end{tabular}

and western lake basins monthly, at two metre intervals through the water column from the surface to 30 $\mathrm{m}$ at the western, and from the surface to $24 \mathrm{~m}$ at the eastern lake basins. Sampling from depths was carried out by an electric pump IMP - Palcek or a Van Dorn bottle.

Phytoplankton qualitative_samples were collected through the whole water column by a plankton net with $20 \mu \mathrm{m}$ mesh size. The freshly gathered material was used for species composition and average cell size determination. The average cell volume for the biomass estimation of individual species was calculated according to formulae by Kellar et. al. (1980) modified by Wetzel \& Likens (1990). Phytoplankton quantitative samples from two metre intervals through the water column were carried out by a pump or a Van Dorn bottle. Samples of $100 \mathrm{ml}$ lake water from each depth taken in plastic bottles were preserved by $1 \mathrm{ml}$ of concentrated formaldehyde and used for the phytoplankton quantitative evaluation. Using a conventional microscope (Leica DMRB) the counting was carried out according to Sournia (1978) in the modified Sedgwick - Rafter (Wetzel \& Likens 1990) 2 ml sedimentation plankton cell. Measurements of the cells were made by an electronic picture analyser. Two thousand millilitres of lake water taken from each depth was used for chlorophyll- $a$ analyses. The international standard procedure ISO 102601992 for chlorophyll- $a$ extraction by methanol was applied.

At the bottom of the lake $(22-30 \mathrm{~m})$ the photosynthetic bacteria (Thiorhodaceae) production was observed simultaneously (Fig. 15). The presence of bacterio-chlorophyll concentration was confirmed by UV. spectrometer.

Chemical analyses were carried out at the ex. Hydrometeorological Institute of Slovenia in Ljubljana, following the Standard Methods for the Examination of Water and Wastewater $(1985,1992)$.

Because no akinetes were found in natural populations of Aphanizomenon slovenicum, we attempted to observe them in material cultivated under laboratory conditions. Several attempts to cultivate the species failed until a December 1998 culture isolated from that September's natural Aphanizomenon - population started to grow. The transfer of a single bundle of $A$. slovenicum from the natural material into a cultivation chamber (Thompson et al. 1988) was carried out by micropipettes and studied under various laboratory conditions at the Bled Limnological station. Isolates were kept in the growing chamber Kambic RK-2 at the temperature $20^{\circ} \mathrm{C}, 12 \mathrm{~h}$ day/night light regime and light intensity of $500 \mu \mathrm{Em}^{-2} \mathrm{~s}^{-1}$. The akinete formation 
was stimulated by application of different light conditions and phosphate concentrations. For this stimulation the general Jaworski's cultivation medium (Thompson et al. 1988) was modified by removal of the phosphorous substances and by the addition of $\mathrm{Na}_{2} \mathrm{PO}_{4}-12 \mathrm{H}_{2} \mathrm{O}$ to the concentration of $1000 \mu \mathrm{g} \mathrm{P.} .^{-1}$. Some samples were cultivated also in the original Jaworski's medium under different light conditions.

Investigated cultures of Aphanizomenon slovenicum, strain Rekar 1998/10 and A. flos-aquae, strain Kosi 1998/11 are kept at the Agency of the Republic of Slovenia, Monitoring Office, Limnological Station Bled.

\section{Results and discussion}

\subsection{Description}

\subsubsection{Latin and English diagnoses}

Aphanizomenon slovenicum Rekar et Hindák, species nova

Fasciculi macroscopici, libere natantes, 5 - $20 \mathrm{~mm}$ longi et $0,4-2,0 \mathrm{~mm}$ lati, viridi-aeruginei, e trichomatibus compositi. Trichomata multicellularia, non ramificata, elongata, cylindrica, recta, subsymmetrica, ad $480 \mu \mathrm{m}$ longa, in media parte (3) - 3,7 - 5,7 - $(7,3) \mu \mathrm{m}$ lata, apice attenuata vel non attenuata, abrupta ; mucus gelatinosus tenuis, sine structura. Cellulae procaryoticae, variabiles : subsphaericae, breviter doliiformes vel cylindricae, $(1,4)-3,9-1,4$ - (19) $\mu \mathrm{m}$ longae, (3) - 4,0-5,7 - (7,3) $\mu \mathrm{m}$ latae, contentu viridi-aerugineo, cum aerotopis numerosis ; cellulae in partibus terminalibus plusminusve cylindricae vel ovales, cum aerotopis sparsis. Hetefocytae solitariae, intercalares, raro 2 per trichoma, cylindricae vel ellipsoidales 5,6 - 8,8 - (14) $\mu \mathrm{m}$ longae et 3,2 - 4,1 (12) $\mu \mathrm{m}$ latae. Akineta elongata ellipsoidaliaque, ab heterocytis remota, intercalaria, solitaria vel raro 2 per trichoma, ab se distantes, in filamento asymmetrice locata, 5,5 - 8,9 - (22) $\mu \mathrm{m}$ longa et 3,3-5,2 $\mu \mathrm{m}$ lata, solum in culturis observata.

Habitatio (locus classicus): In plancto lacus Bled, Slovenia, coll. 1997 - 1998 (leg. Spela Rekar).

Typus : plankton sample, Rekar $n^{\circ} 98 / 10,05.05 .2002$, depositum in museo The Slovenian Museum of Natural History, Ljubljana (Labacum), Slovenia.

Iconae.typicae : figurae nostrae 2-9.

Etymologia : Species secundum regionem localitatis nominata.

English description. Bundles macroscopic, 5 - $20 \mathrm{~mm}$ long and $0.4-2.0 \mathrm{~mm}$ wide, free floating, with trichomes in bundles. Trichomes multi-celled, not ramified, elongated, cylindrical, straight, subsymmetric, up to $480 \mu \mathrm{m}$ long, in central part (3) - 3.7 - 5.7 - (7.3) $\mu \mathrm{m}$ wide, bluntly pointed, not narrowed toward the ends; elongated terminal cells slightly broader, without a sheath. The mucilage layer is negligible. Vegetative cells prokaryotic and of variable shape : shortly or long cylindrical, sometimes broader than long, slightly to noticeably constricted at the cross walls, or barrelshaped, (1.4) - 3.9 - 12.4 - (19) $\mu \mathrm{m}$ long, (3) - 4 - 5.7 - (7.3) $\mu \mathrm{m}$ wide, with many aerotopes. Terminal cells sometimes more elongated, broader, rarely conical, with many granules near the cell walls but without conspicuous aerotopes. Cells in central part appear blue-green, towards the terminal ends appear a paler blue-green. Heterocyte 1 , rarely $2-3$ in the trichome, intercalar, sometimes terminal after breaking of the trichome, ellipsoidal to spherical, 5.6 - 8.8 - (14) x 3.2 - 4.1 (12) $\mu \mathrm{m}$. Akinetes one or rarely two in the trichome, short cylindrical, 5.5 - 8.9 - (22) x $3.3-5.2 \mu \mathrm{m}$, distant from heterocytes, observed only in cultures.

\subsubsection{Morphology of bundles, trichomes and cells}

Macroscopic appearance of bundles of the new species were approximately the same as in the type species, i.e. bundles consisted of macroscopic elongated flakes composed of bundles with plus - minus parallel arranged trichomes. Bundles were free floating, 5 - 20 $\mathrm{mm}$ long and $0.4-2 \mathrm{~mm}$ wide (Figs 10,11). During the mass development in 1997 they were conspicuously concentrated at water depth in a layer from 10 to $20 \mathrm{~m}$ and never forming a surface water bloom. The maximum density of Aphanizomenon trichomes was found at $14 \mathrm{~m}$ : in June 70 trichomes. $\mathrm{ml}^{-1}$, in July 385 trichomes. $\mathrm{ml}^{-1}$ and in August 655 trichomes. $\mathrm{ml}^{-1}$. However, this species appeared throughout other layers of the whole water column of the lake but in less abundance. Bundles were frequently composed of subbundles oriented in different directions and formed floating flakes, firm, but easily disintegrating after their transfer into flasks. Colour of bundles was intensive blue-green to olive green. Buoyancy mediated vertical migration was the characteristic way for population movement. The motion of trichomes within colony bundles was evident but slithering of solitary trichomes was not observed.

Trichomes were multi-celled, not ramified, cylindrical, mostly straight, sometimes slightly curved at the ends, subsymmetric (cf. Komárek \& Anagnostidis $1989)$, and variable in length : ranging from several cells to average 220 to $480 \mu \mathrm{m}$, (3) - 4.0 - 5.7 - (7.3) $\mu \mathrm{m}$ wide, without a sheath (Figs 3-6, 9, 11-13). Trichomes in bundles overlapped each other, easily separated and fragmenting after sampling. Generally, three types of trichomes could be distinguished according to the cell shape (Figs 3-6, 9, 11, 12), i.e. trichomes consisting of : (i) cylindrical cells, (ii) barrel-shaped cells of different length, (iii) both types of cells, i.e. cylindrical and barrel-shaped. In some cases parts of the trichome looked like «growth zones», with highly variable cell length. Connections between morphologically different parts of the trichomes were obviously 

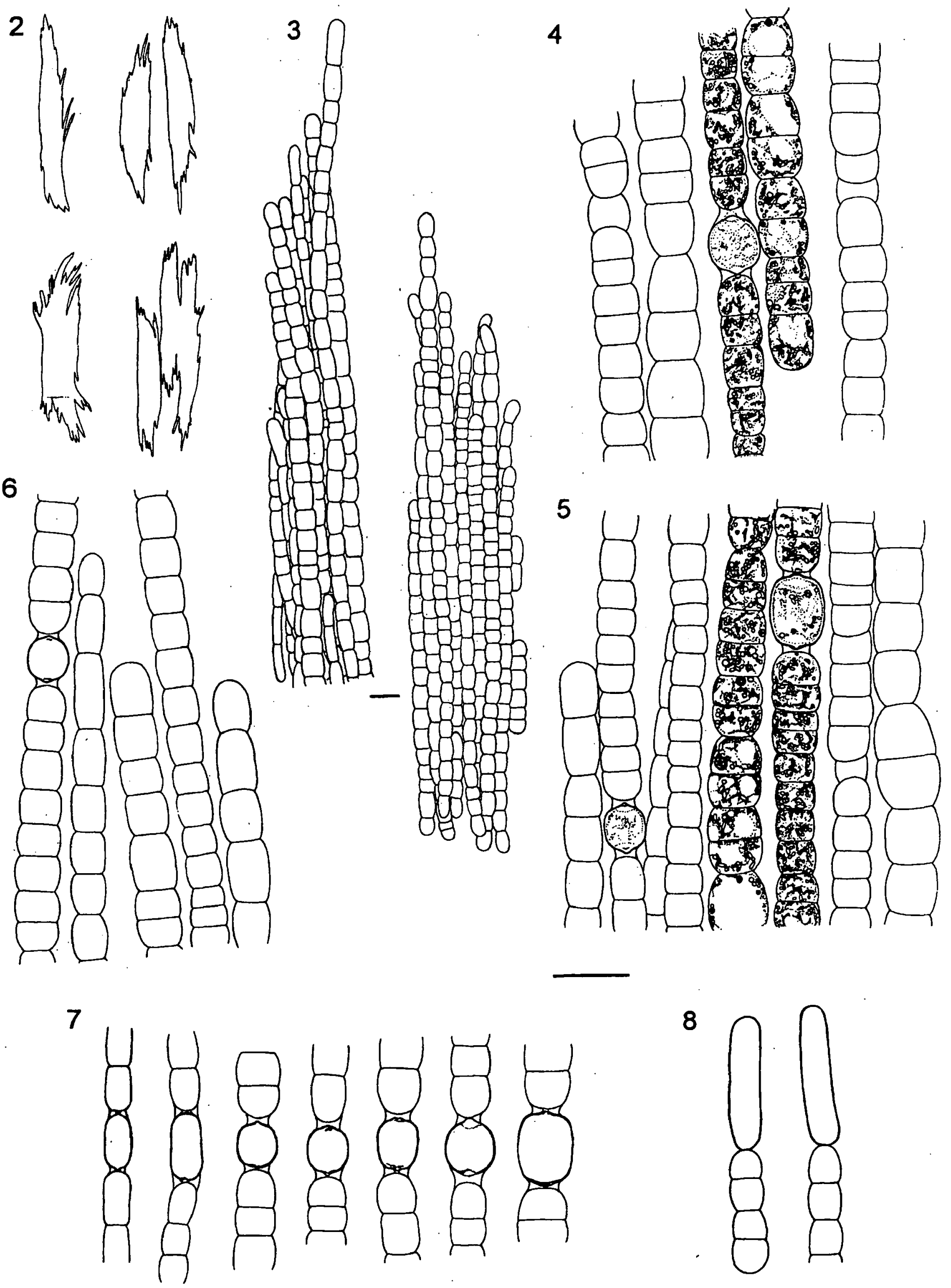

Figs 2-8. Aphanizomenon slovenicum sp. nov. $2:$ bundles $; 3-6:$ trichomes ; $7:$ heterocytes $; 8:$ akinetes. Scale (Figs 4 - 8): $10 \mu \mathrm{m}$.

$4-8): 10 \mu \mathrm{m}$.
Figs 2-8. Aphanizomenon slovenicum nov. sp. 2 : faisceaux ; 3-6: trịchomes ; $7:$ hétérocytes ; $8:$ akinètes. Echelle (Figs 4 8) : $10 \mu \mathrm{m}$. 

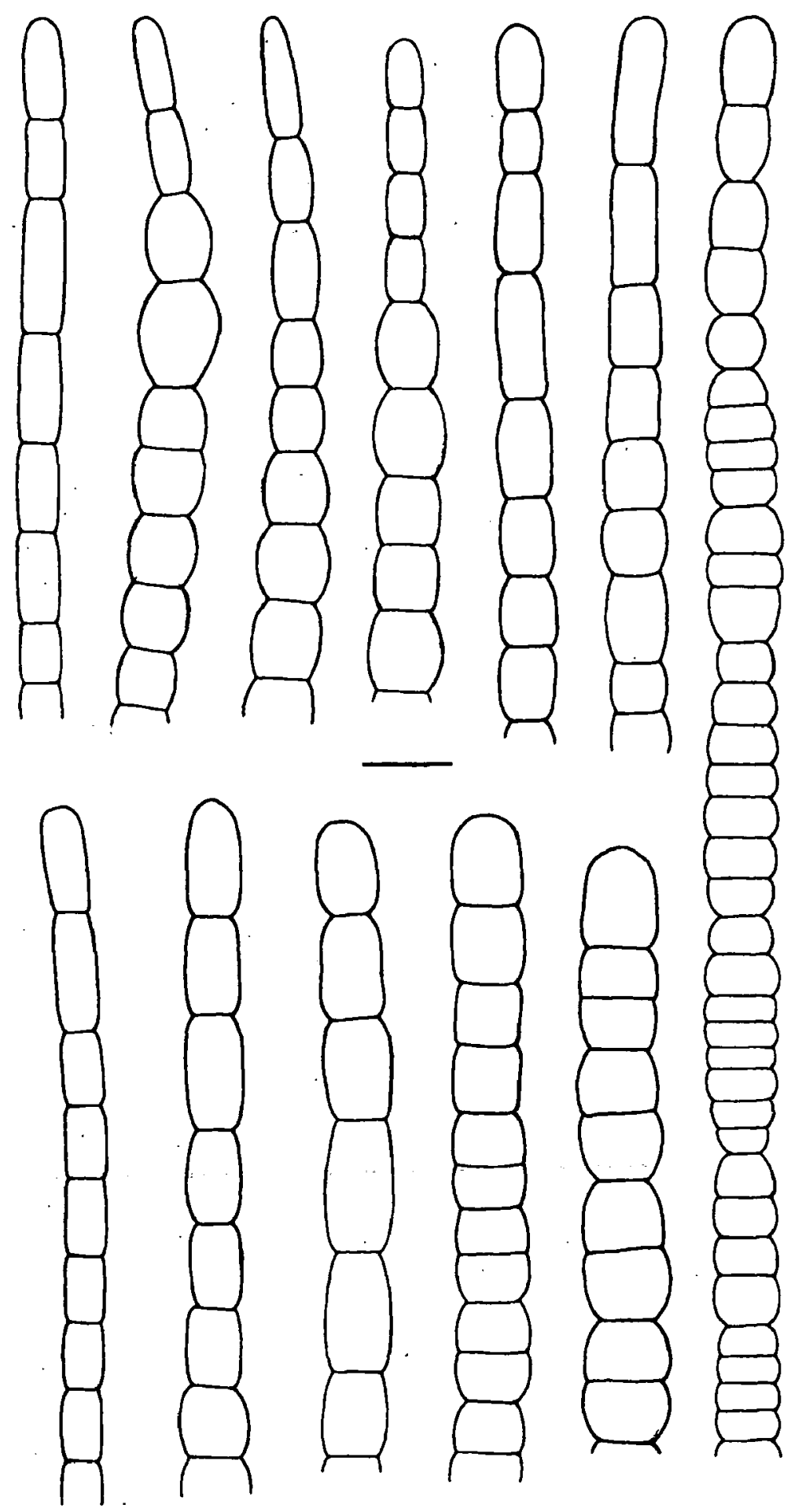

Fig. 9. Aphanizomenon slovenicum sp. nov., shape of trichomes. Scale : $10 \mu \mathrm{m}$.

Fig. 9. Aphanizomenon slovenicum nov. sp., forme des trichomes. Echelle : $10 \mu \mathrm{m}$.

weak. Aerotopes were large, conspicuous and present in all types of trichomes (Figs 4, 5, 11-13). The ends of trichomes varied considerably (Figs 3, 5, 9), and consisted of : (i) normal vegetative cells with rounded ends and with many aerotopes, (ii) elongated and slightly narrow or wider cells, with small aerotopes or cells without them (iii) a group of 2 - 5 broadly ellipsoidal to spherically oval cells, mostly without visible aerotopes, (iv) 1-2 spherical cells with small aerotopes or without them, (v) «growth zones» with (2) - 3 - 6 swollen-tipped cells of different length, broader than longer, or longer than wider, with visible aerotopes. Similar trichomes with vegetative cells of varying shapes and with similar "growth zones» were observed in a population of $A$. hungaricum Kom. - Legn. et Mátyás which occurred only in solitary trichomes in lake Kis Balaton in Hungary (Komárková - Legnerová \& Mátyás 1995). The mucilage layer is narrow or negligible. Trichomes broke easily anywhere but namely during microscopy and after preservation.

Vegetative cells were of various shape, depending on the age and their position in the trichome. Good growing trichomes consisted mostly of short cylindrical cells, sometimes broader than longer, slightly to markedly constricted at the cross walls, or of barrel-shaped cells, both containing many conspicuous aerotopes and granules. At the ends of trichomes a group of $3-4$ cells were sometimes more elongated and wider than normal cells (on average $6.7 \mu \mathrm{m}$ long and $3.9 \mu \mathrm{m}$ wide, Fig. 9 ; morphological variability of end cells see description in the previous paragraph). In some trichomes these terminal cells were markedly prolongated and hyaline, or rounded to swollen, rarely upright cut at the ends where trichomes were broken, with fewer aerotopes. Colour of cells in central parts were intensively blue - green or olive green, at the end parts not so intensive or pale blue - green. Dimensions of vegetative cells in the middle of trichome (cylindrical cells) were $\mathrm{L}$ (1.8) - 3.9 - (6.1) $\mu \mathrm{m}$ and $\mathrm{W}(4.4)$ - 5.0 - (5.8) $\mu \mathrm{m}$; prolongated terminal cells : L $12.4-(19.0) \mu \mathrm{m}$ and $\mathrm{W}$ (3.0) - 4.6 - (6.9) $\mu \mathrm{m}$; wider vegetative cells : $L$ (1.4) 4.0 - (6.7) $\mu \mathrm{m}$ and $W(5)$ - 5.7 - (7.3) $\mu \mathrm{m}$ (Table 4).

Heterocytes (Figs 4-7, 12) resembled those of $A$. flos-aquae but formed infrequently or were very rarely in natural populations, generally 1 in number, rarely 2 - (3), sometimes together, located intercalar in the middle part of trichomes, or terminal after breaking of the trichome. They were short ellipsoid to sphericaloval in shape, 5.6 - 8.8 (14) $\times 3.2$ - 4.1 - (12) $\mu \mathrm{m}$, i.e. of similar length but thinner than in A. flos-aquae (Table 5). Orange bodies were situated in both polar regions and irregular small bright bodies were conspicuous .

Akinetes (Figs 8,13) were found only in a cultured strain isolated from the September 1998 sampling. Formation of akinetes was observed 4-6 weeks after the lag phase of the culture growth, in temperature about $20^{\circ} \mathrm{C}, 12 \mathrm{~h}$ day/light regime and light intensity $100 \mu \mathrm{E} \cdot \mathrm{m}^{-2} \cdot \mathrm{s}^{-1}$ in the unchanged Jaworski's medium. All other growth conditions did not produce akinetes (Table 3). Therefore we can assume that decreasing the 


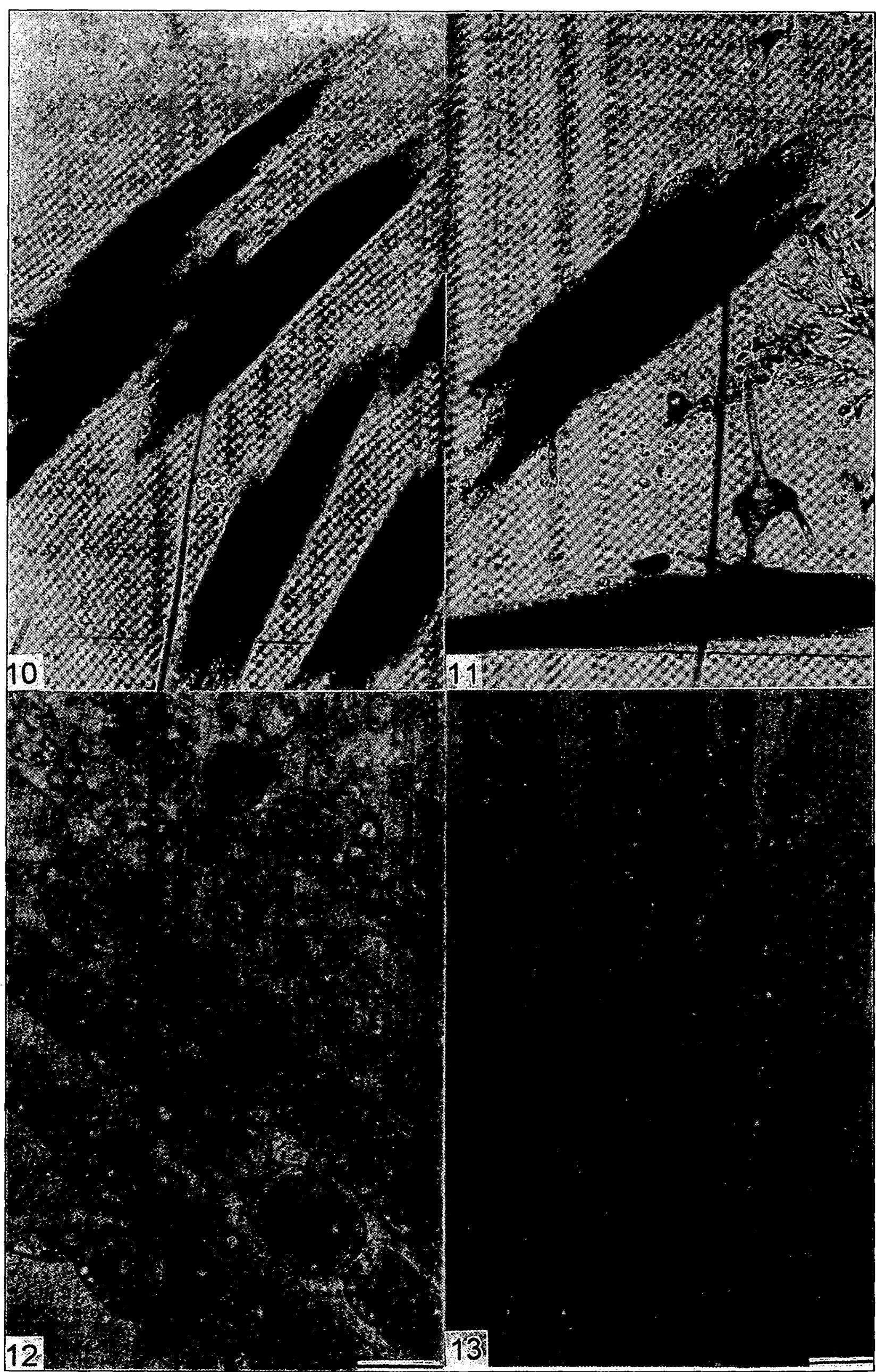

Figs 10-13. Aphanizomenon slovenicum sp. nov., 10, 11 : shape of bundles ; 12 : trichomes with heterocytes ; 13 : trichome with an akinete (a) and heterocyte (h). Scale (Figs 12,13):10 $\mu \mathrm{m}$.

Figs 10-13. Aphanizomenon slovenicum nov. sp. 10-11 : forme des faisceaux ; 12 : trichomes avec hétérocytes ; 13 : trichomes avec un akinète (a) et un hétérocyste (h). Echelle (figs 12-13):10 $\mu \mathrm{m}$. 
Table 3. Akinete formation in the strain of Aphanizomenon slovenicum strain Rekar $1998 / 10$ at $20^{\circ} \mathrm{C}$, different light conditions and different phosphate concentrations, after six week cultivation.

Tableau 3. Formation d'akinète dans la souche de Aphanizomenon slovenicum, souche Rekar 1998/10 à la température de $20^{\circ} \mathrm{C}$, sous différentes conditions d'éclairement et de concentration en phosphate après 6 semaines de culture.

\begin{tabular}{ccc}
\hline Akinete formation & $\begin{array}{c}\text { Light intensity } \\
\mu \mathrm{E} \cdot \mathrm{m}^{-2} \cdot \mathrm{s}^{-1}\end{array}$ & $\begin{array}{c}\text { Phosphorus concentration } \\
\mu \mathrm{g} \mathrm{P} \mathrm{^{-1 }}\end{array}$ \\
\hline noticed & 100 & $5.9^{*}$ \\
not noticed & 500 & 1000 \\
not noticed & 500 & $5.9^{*}$ \\
not noticed & (cultivation in the dark) & 1000 \\
not noticed & 500 & 0 \\
\hline
\end{tabular}

* Concentration in the original Jaworski's medium

light intensity could be the trigger factor for the akinete formation. Akinetes were observed in less than $10 \%$ of trichomes. They were mainly solitary in the trichome, rarely two and distant each other. They were elongated, $5.5-8.9$ - (22) $\mu \mathrm{m}$ long and $3.3-5.2 \mu \mathrm{m}$ wide and distant from the heterocyte, i.e. the trichome pattern is subsymmetrical. As can be seen from Table 5, the akinetes studied in investigated cultures of $A$. flosaquae were much longer $[(18)-22.7-(35) \mu \mathrm{m}]$ and wider [(6) - 7.1 - (8) $\mu \mathrm{m}]$ than in A. slovenicum [(5.5) 8.9 - (22) x (3.3) - 3.8 - (5.2) $\mu \mathrm{m}]$. However, the akinetes of the new species were observed only in cultures, therefore they probably not reached maturity in laboratory conditions.

\subsubsection{Dominant and accompanying species in the phytoplankton in 1990-2001}

Cyanophytes have been frequently forming massive, long lasting planktic water bloom in Lake Bled during the second part of the $20^{\text {th }}$ century. The water bloom was regularly caused by the oscillatorian species Planktothrix rubescens (DC. ex Gom.) Anagn. et Komárek (syn. Oscillatoria rubescens DC. ex Gom.) (Vrhovsek \& Kosi 1981), with the exception in 1990 when the bloom was caused by the nostocalean species Aphanizomenon flos - aquae (L.) Ralfs ex Born. et Flah. After 1990 just single trichomes of this species were found in the phytoplankton, and generally $P$. rubescens dominated during the summer stagnant period in the metalimnion. A. slovenicum was found for the first time in May 1997 and disappeared in December 1998. In 1999 - 2000 P. rubescens dominated again, and $A$. slovenicum has not been observed in Lake Bled since. Gradually decreasing the total phytoplankton productivity was characteristic for the period of 1991 1997, but it increased again in 1998 and especially du- ring the summer of 1999 when an extended planktic water bloom of $P$. rubescens covered the lake surface. Planktothrix rubescens represented about $95 \%$ of the total phytoplankton biomass in the lake from September 1999 to March 2000 (Fig. 19).

The major accompanying species of the phytoplankton assemblages in the summer 1997 were cyanophytes Anabaena flos-aquae, Aphanothece spp., Aphanocapsa spp., Chroococcus limneticus, Merismopedia sp., Microcystis aeruginosa, Snowella littoralis, bacillariophytes Achnanthes lanceolata, Asterionella formosa, Cocconeis placentula, Cyclotella comta, Fragilaria acus, F. crotonensis, F. ulna, Gyrosigma sp., Navicula rhynchocephala, Nitzschia acicularis, Stephanodiscus sp., chrysophytes Dinobryon ( $D$. divergens, $D$. sertularia), and Mallomonas caudata, Uroglena americana, and sporadically Bitrichia phaseolus and Chrysamoeba histolitica, dinophytes Ceratium hirundinela, species of the genus Peridinium (P. cinctum, $P$. inconspicuum, $P$. willei) and Gymnodinium (G. fuscum, G. mirabile), rarely also Glenodinium oculatum, cryptophytes Cryptomonas ovata, chlorophyte flagellates (Volvocales) Chlamydomonas passiva, Phacotus lenticularis, Pandorina morum. The diversity of representatives of Chlorococcales was quite rich, consisting primarily of Ankyra ancora, Botryococcus braunii, Chlorella vulgaris, Coenococcus planctonicus, Lagerheimia gevenensis, Oocystis lacustris, O. parva, Planktosphaeria gelatinosa, Scenedesmus armatus, S. quadricauda, Tetrachlorella alternans, Tetraedron minimum, Tetrastrum komarekii, Willea irregularis. Some simple ulotrichalean algae (e.g. Elakatothrix gelatinosa, Koliella longiseta) and desmids (species of the genera Cosmarium and Staurastrum) sporadically occurred.

Species composition of the phytoplankton in summer 1998 was similar, but Planktothrix rubescens be- 
came strongly dominant and Aphanizomenon slovenicum occurred in a very small quantity.

\subsubsection{Vertical and horizontal distribution of $A$. slove- nicum in Lake Bled}

As already mentioned, Aphanizomenon slovenicum was initially noticed in Lake Bled in May 1997 when a

Table 4. Average dimensions $(\mu \mathrm{m})$ of morphologically different cells in trichomes of Aphanizomenon slovenicum from Lake Bled in May and July 1997.

Tableau 4. Dimensions moyennes $(\mu \mathrm{m})$ des cellules morphologiquement différentes de Aphanizomenon slovenicum en mai et juin 1997 dans le lac Bled.

\section{Average dimensions of \pm cylindrical cells}

\begin{tabular}{ccc}
\hline $\begin{array}{c}\text { Position of the cell } \\
\text { in trichome }\end{array}$ & Length & Width \\
\hline $1^{\text {st }}$ & 7.0 & 4.1 \\
\hline $2^{\text {nd }}$ & 6.4 & 4.4 \\
\hline $3^{\text {rd }}$ & 5.8 & 4.7 \\
\hline $4^{\text {th }}$ & 5.1 & 4.5 \\
\hline $5^{\text {th }}$ & 4.4 & 4.7 \\
\hline $6^{\text {th }}$ & 3.8 & 4.5 \\
\hline
\end{tabular}

Average dimensions spherical-oval cells

\begin{tabular}{ccc}
\hline $\begin{array}{c}\text { Position of the cell } \\
\text { in trichome }\end{array}$ & Length & Width \\
\hline $1^{\text {st }}$ & 8.2 & 4.7 \\
\hline $2^{\text {nd }}$ & 7.2 & 5.1 \\
\hline $3^{\text {rd }}$ & 6.5 & 5.6 \\
\hline $4^{\text {th }}$ & 6.3 & 5.7 \\
\hline $5^{\text {th }}$ & 5.5 & 6.4 \\
\hline $6^{\text {th }}$ & 5.7 & 6.7 \\
\hline $7^{\text {th }}$ & 5.6 & 6.9 \\
\hline $8^{\text {th }}$ & 6.3 & 5.5 \\
\hline $9^{\text {th }}$ & 7.7 & 6.8 \\
\hline
\end{tabular}

Average dimensions of cells of "growing zone"

\begin{tabular}{ccc}
\hline $\begin{array}{c}\text { Number of cells } \\
\text { in the zone }\end{array}$ & $\begin{array}{c}\text { Length of the } \\
\text { whole "zone" }\end{array}$ & Width \\
\hline 2 & 8.5 & 5.1 \\
\hline 2 & 6.6 & 5.4 \\
\hline 2 & 6.1 & 8.6 \\
\hline 2 & 5.2 & 5.5 \\
\hline 3 & 12.5 & 6.3 \\
\hline 3 & 12.3 & 6.5 \\
\hline 4 & 20.4 & 5.2 \\
\hline 4 & 16.3 & 5.9 \\
\hline
\end{tabular}

typical metalimnetic population was formed at the depths between 10 and $20 \mathrm{~m}$ with the abundance of 40 - 70 trichomes per $\mathrm{ml}$ (Fig. 14). The population reached its maximum with 405 to 655 trichomes per $\mathrm{ml}$ in August at the depth from 14 to $16 \mathrm{~m}$, respectively, but it declined very quickly to 40 trichomes in September. In October only solitary trichomes were found at the depth of $14 \mathrm{~m}$. From June to September the population maximum was strictly at the depth of $14 \mathrm{~m}$ but the tendency of population to sinking was noticed.

Also during the summer stratification in 1998, $A$. slovenicum formed a much smaller population with the maximum abundance of 27 trichomes per $\mathrm{ml}$ in September at the depths of 12 to $16 \mathrm{~m}$. In November and December the motion of populations to the surface was observed. In November 20 trichomes per $\mathrm{ml}$ were found in the layer from the surface to the depth of 10 $\mathrm{m}$. Since then $A$. slovenicum has no longer been observed any more in Lake Bled, and Planktothrix rubescens prevailed again (Fig. 19).

Vertical and horizontal distribution of the natural phytoplankton population is a function of specific physical and chemical conditions, i.e. light conditions, availability of micro- and macronutrients and specific water turbulent mixing pattern (Reynolds 1984). Aphanizomenon flos-aquae and A. slovenicum did not differ substantially in their vertical distribution in Lake Bled but light penetration into the depth was especially different in 1990 compared to 1997 (Fig. 18).

In the depths of $10-20 \mathrm{~m}$ where $A$. slovenicum occurred in great abundance from May to August 1997, the temperature varied from 7.8 to $9.7^{\circ} \mathrm{C}$, the $\mathrm{pH}$ value from 7.8 to 8.1 and the average total phosphorus concentration was $11.7 \mu \mathrm{g} \mathrm{P} \cdot 1^{-1}$. At the same depths nitrate represented the majority $(99.95 \%)$ of the total inorganic nitrogen in a quantity of $362 \mu \mathrm{g} \mathrm{N} \mathrm{l}^{-1}$. From May to October 1997 the average Secchi depth exceeded $10 \mathrm{~m}$. The inflow of the Radovna river was adjusted to $0.4 \mathrm{~m}^{3} \cdot \mathrm{s}^{-1}$ and inflow did not vary during the Aphanizomenon occurrence in the lake.

The proportion between phosphorus and nitrogen in the lake was extremely high in 1997 because of the low phosphorus and high nitrogen concentration (Figs 16, 17 ; Table 2.). In the following years $N: P$ ratio was reduced by the increasing of phosphorus concentration and decreasing of nitrogen concentration.

Aphanizomenon slovenicum formed a larger population in the period of a significantly lower phytoplankton productivity when the average total phytoplankton biomass was estimated to be only $0.6 \mathrm{~g} \mathrm{~m}^{-3}$, and followed Dinobryon divergens (Chrysophyceae) dominan- 
Table 5. Characteristics of the investigated cultures of Aphanizomenon flos-aquae and A. slovenicum.

Tableau 5. Caractéristiques de Aphanizomenon flos-aquae et de A. slovenicum en cultures.

\begin{tabular}{|c|c|c|}
\hline & Aphanizomenon fios aquae, strain Kosi 1998/11 & Aphanizomenon slovenicum, strain Rekar 1998/10 \\
\hline $\begin{array}{l}\text { Macroscopic } \\
\text { Outlook }\end{array}$ & $\begin{array}{l}\text { Trichomes with a tendency to form bundles; bundles } \\
\text { more easily disintegrating than in } A \text {.slovenicum; } 2-5 \\
\text { trichomes can be stuck more tightly; bundles of } \\
\text { different formations; trichomes in bundles oriented } \\
\text { always into the same direction; majority of trichomes buoyar } \\
\text { located at the surface of the cultivating flask, } \\
\text { only some trichomes located at the bottom and not } \\
\text { forming bundles }\end{array}$ & $\begin{array}{l}\text { Trichomes parallel in firm, not easy disintegrating bundles; } \\
\text { individual bundles united together in a specific (disorderly) } \\
\text { way, some bundles oriented in different directions, } \\
\text { even perpendicular to each other, forming macroscopic } \\
\text { more longer (5-20 mm) than wider (0.4-2.0 mm) loating } \\
\text { flakes (noticed also in natural populations in 1998) }\end{array}$ \\
\hline Colour & $\begin{array}{l}\text { Olive green but not so intensive as in } A \text {. slovenicum; } \\
\text { with ageing getting browner and producing a lot of } \\
\text { akinetes }\end{array}$ & $\begin{array}{l}\text { Intensive olive green; with ageing getting pale, with a very few } \\
\text { or lack of akinetes }\end{array}$ \\
\hline Aerotopes & $\begin{array}{l}\text { Mostly present but with different arrangements, neither } \\
\text { unique, nor typical }\end{array}$ & $\begin{array}{l}\text { Lager and occupying almost the whole entire of cells } \\
\text { normally linked along cell walls; sometimes united together }\end{array}$ \\
\hline Trichomes & $\begin{array}{l}\text { (1) normal trichomes with_t cylindrical cells; } \\
\text { (2) thinner trichomes without aerotopes in cylindrical cells } \\
\text { (prints 3) } \\
\text { (3) wider trichomes with spherical to barrel-shaped cells } \\
\text { and expressive aerotopes, very varying in length; near wall }\end{array}$ & $\begin{array}{l}\text { (1) normal trichomes with variable length of cells; } \\
\text { (2) thinner trichomes without expressive aerotopes in } \pm \text {-cylindric } \\
\text { or slightly barrel like cells (prints 4) } \\
\text { (3) trichomes with spherical-shaped cells are rare }\end{array}$ \\
\hline $\begin{array}{l}\text { Ends of } \\
\text { trichomes }\end{array}$ & $\begin{array}{l}\text { (1) a normal vegetative cell with aerotopes and round apex; } \\
\text { (2) elongated terminal cells: } 2-3 \text { elongated cells thinner } \\
\text { or not and almost empty, without aerotopes, granulated near } \\
\text { cell walls } \\
\text { (3) a spherical terminal cell: one big empty spherical cell, } \\
\text { little granulated near cell walls ends trichome }\end{array}$ & $\begin{array}{l}\text { (1) a short semicircle or normal vegetative cell: with round } \\
\text { apex and aerotopes } \\
\text { (2) elongation of terminal cells: } 2 \text { cells at the end of trichome } \\
\text { prolongated, without aerotopes and granulated near cell walls, } \\
\text { wider at the base where are sticked together } \\
\text { (3) prolongated terminal cells: one long cell wider in the } \\
\text { middle }\end{array}$ \\
\hline $\begin{array}{l}\text { Cell } \\
\text { dimensions* }\end{array}$ & 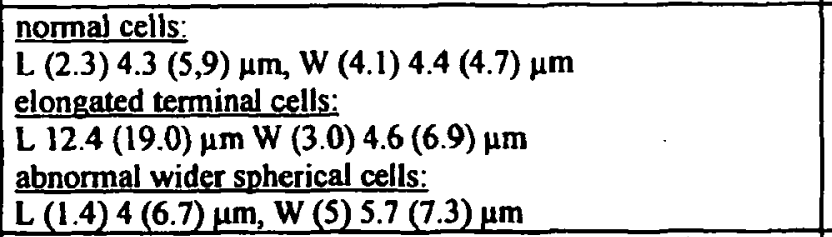 & $\begin{array}{l}\text { normal cells: } \\
\mathrm{L}(2.2) 3.2(3.8) \mu \mathrm{m}, \mathrm{W}(3.2) 3.6(4.1) \mu \mathrm{m} \\
\text { elongated terminal cells: } \\
\mathrm{L} 6.4(9.0) \mu \mathrm{m}, \mathrm{W}(3.3) 3.8(4.3) \mu \mathrm{m}\end{array}$ \\
\hline Heterocytes & $\begin{array}{l}1 \text { - } 3 \text { in a trichom, cylindrical or } \pm \text { spherical, then shorter } \\
L 7.5 \text { (9.1) } 9.5 \mu \mathrm{m}, W \text {. } 5.5 \text { (5.9) } 7.1 \mu \mathrm{m}\end{array}$ & $\begin{array}{l}\text { present only in 6-8 old week cultures; morphologically } \\
\text { similar to heterocystes of } A \text {. flos-aquae; in the middle part of } \\
\text { trichomes; 1, rarely } 2 \text {, sometimes together } \\
\text { L } 5.6(7.7) 8.8 \mu \mathrm{m}, \text { W } 3.2(3.5) 4.1 \mu \mathrm{m} \\
\end{array}$ \\
\hline Akinetes & $\begin{array}{l}1-2 \text { in a trichome; } 3 \text { - } 6 \text { weeks after inoculation (depends on } \\
\text { growth conditions), frequent } \\
\mathrm{L}(18) 22.7(35) \mu \mathrm{m} \mathrm{W}(6) 7.1(8) \mu \mathrm{m}\end{array}$ & $\begin{array}{l}\text { not present in young culture; appear after heterocytes 8-10 } \\
\text { weeks after inoculation; very rare } \\
\mathrm{L}(5.5) 8.9(22) \mu \mathrm{m}, \mathrm{W}(3.3) 3.8(5.2) \mu \mathrm{m}\end{array}$ \\
\hline
\end{tabular}

* Measurements were made by electronic picture analyser

ce at the depths between 4 and $6 \mathrm{~m}$ in June 1997. The lake transparency was high (over $10 \mathrm{~m}$ ) which reflected the specific light conditions and extraordinary light penetration to the depths (Fig. 18). At the bottom of the lake $(22-30 \mathrm{~m})$ the production of the photosynthetic bacteria (Thiorhodaceae) was simultaneously observed near the bottom of the lake (22-30 m) (Fig. 15).

Low productivity or nearly absence of the usual dominant cyanophyte Planktothrix rubescens could have also be a very important factor in the occurrence of other cyanophyte species in Lake Bled (Fig. 19). Specific environmental conditions favour particular phytoplanktic species throughout their process of competition for the nutrients and light resources. The winner in this battle is a so-called predominant species whose adaptation ability is best suited to the specific conditions. The $A$. slovenicum short mass appearance in Lake Bled during the summer of 1997 , low abundance in 1998 and final extinction in 1999 puts it among the poor competitors.

\subsubsection{Characteristics of cultures Aphanizomenon flos- aquae and $A$. slovenicum}

Bundles of Aphanizomenon flos-aquae formed a big surface water bloom in Lake Bled in 1990. Before this period no data reporting the Aphanizomenon appearance could be found (Vrhovsek \& Kosi 1981). Unfortunately phytoplankton samples from 1990 were not well preserved, and thus we are not able to compare this population of $A$. flos-aquae with $A$. slovenicum. Therefore a culture of $A$. flos-aquae, isolated from the 


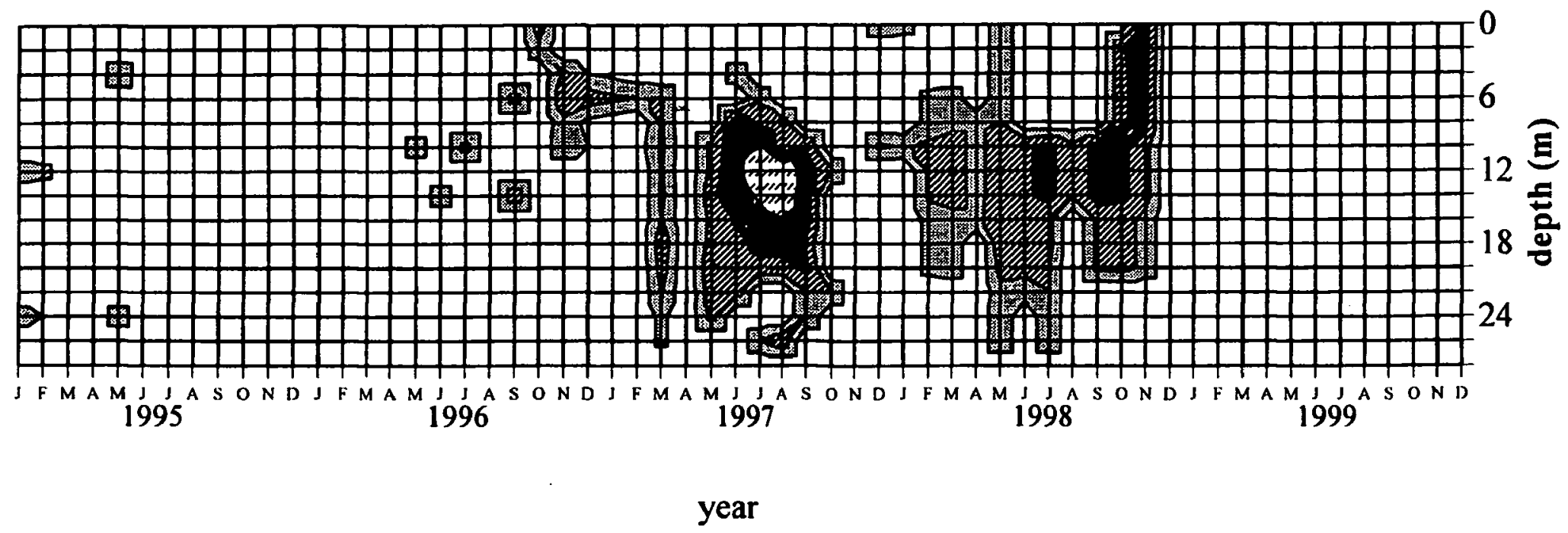

Fig. 14. Distribution of Aphanizomenon slovenicum in Lake Bled in 1995 - 2000.

Fig. 14. Distribution verticale de Aphanizomenon slovenicum dans le lac Bled de 1995 à 2000.

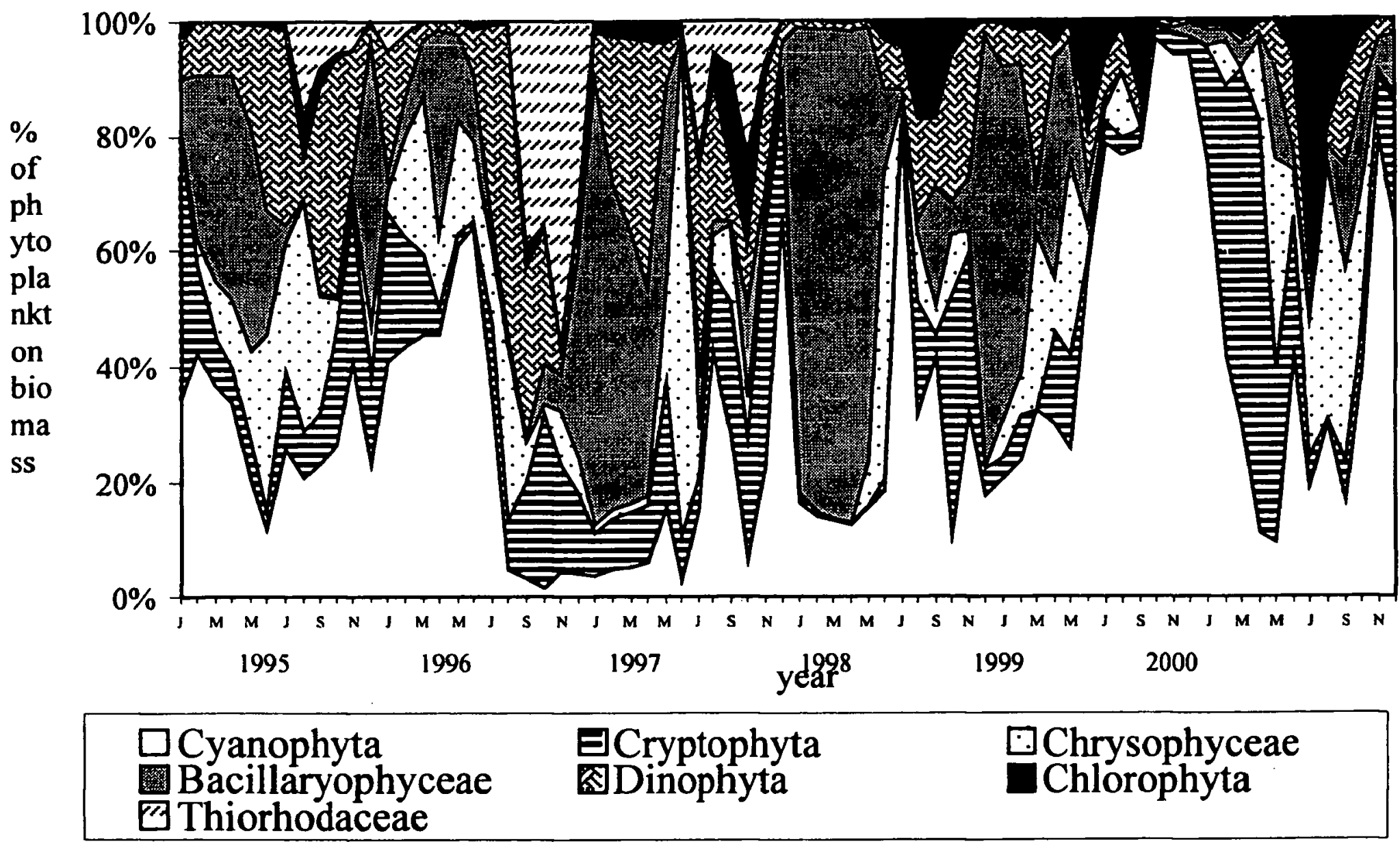

Fig. 15. Composition of the phytoplankton community in Lake Bled in $1995-2000$.

Fig. 15. Composition de la communauté phytoplanctonique dans le lac Bled de 1995 à 2000. 


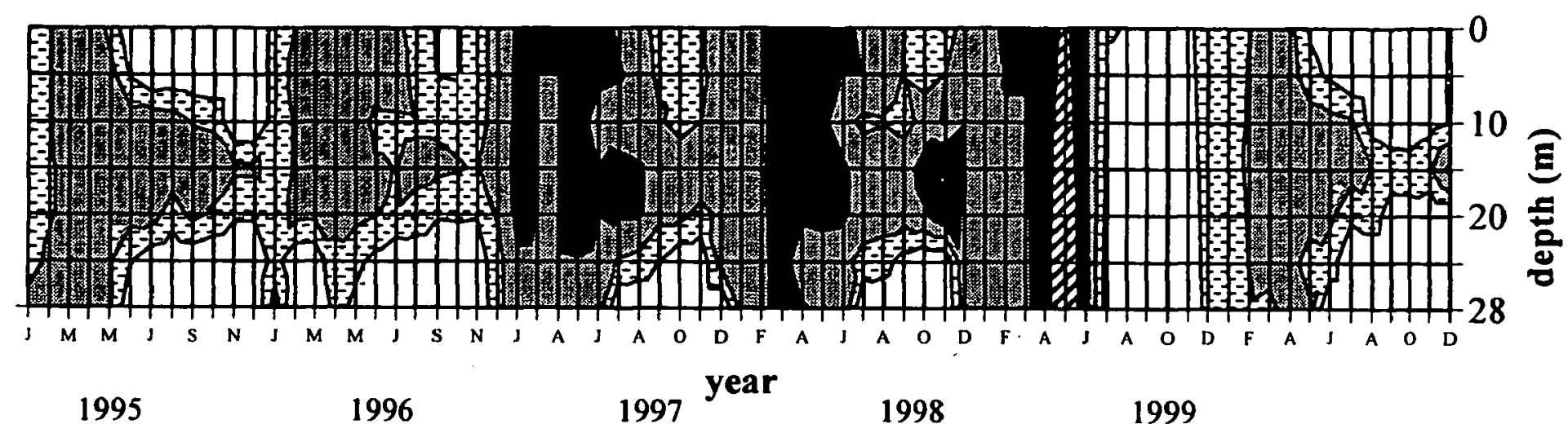

nitrate concentration

\begin{tabular}{llllll|}
$\mathrm{mg} \mathrm{NO}_{3} \mathrm{I}^{-1}$ & $\square 0.0-0.5$ & $\mathbf{6} 0.5-1.0$ & 圈 1.0-1.5 & $\mathbf{0} 1.5-2.0$ & $\square 2.0-2.5$ \\
\hline
\end{tabular}

Fig. 16. Vertical distribution of nitrate in Lake Bled in 1995 - 2000.

Fig. 16. Distribution verticale de l'azote nitrique dans le lac Bled de 1995 à 2000.

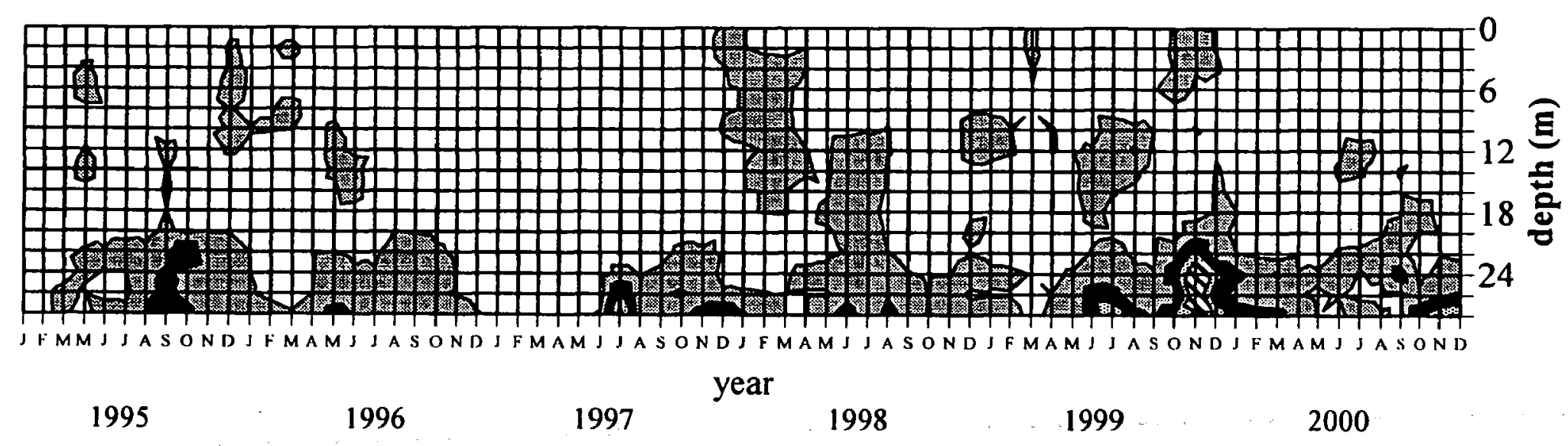

$P$ total concentration

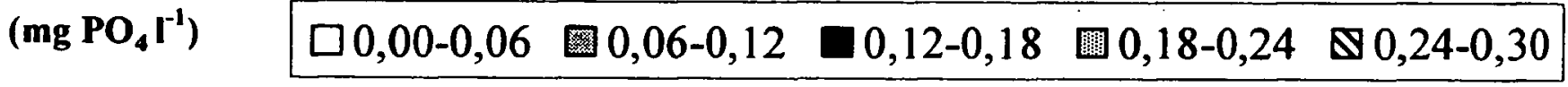

Fig. 17. Vertical distribution of total phosphorus in Lake Bled in 1995 - 2000.

Fig. 17. Distribution verticale du phosphore total dans le lac Bled de 1995 à 2000.

fishpond at Ledava (NE Slovenia, in the Pannonia lowland, about $150 \mathrm{~km}$ from Bled), was studied to be sure of the main characteristics of both species. A survey of our results from both cultures, A. flos-aquae and A. slovenicum, is given in Table 5.

As can be seen from Table 5, the main diagnostic features of both species, A. flos-aquae and A. slovenicum, were also expressed under laboratory conditions. Generally speaking, the cells of the new species were smaller and different in shape than those of the type species, shortly cylindrical, slight to noticeably constricted at the cross walls, or barrel-shaped, with many conspicuous aerotopes and granules. End cells were sometimes more elongated and wider or narrower than normal cells. On the other hand, vegetative cells in the culture of $A$. flos-aquae were cylindrical, unconstricted at the cross walls and larger than in A. slovenicum. The majority of $A$. flos-aquae trichomes were buoyant, located at the surface of the culture flask, and only some trichomes sunk to the bottom and did not form bundles. On the other hand, in the culture of $A$. slovenicum trichomes formed macroscopic floating flakes similar to natural populations from 1998. Both strains studied differed markedly in their ability to form heterocytes and akinetes in laboratory conditions. 


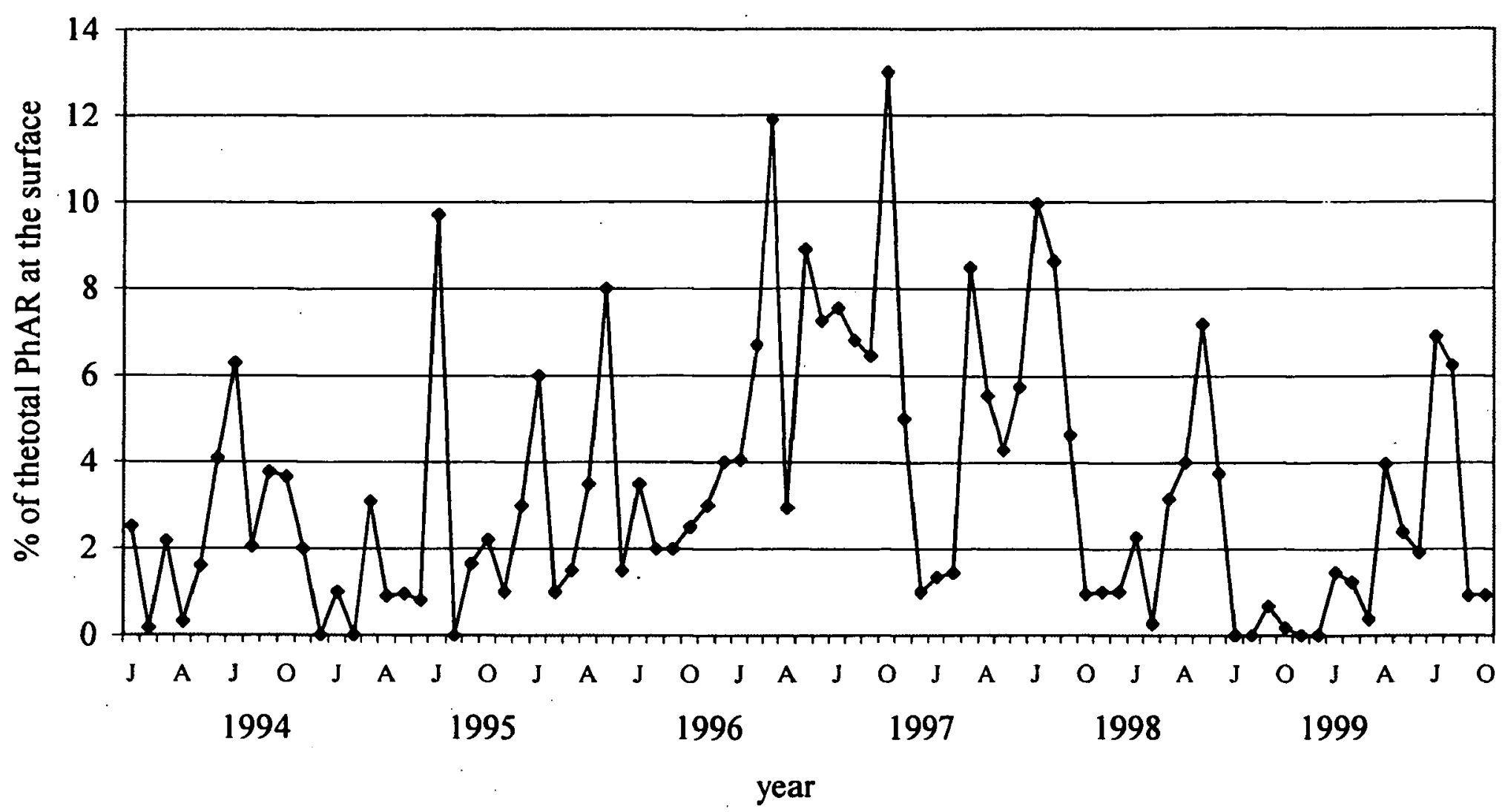

Fig. 18. Percentage of PhAR radiation at a depth of $10 \mathrm{~m}$ in Lake Bled in $1994-2000$.

Fig. 18. Pourcentage des radiations actives pour la photosynthèse dans le lac Bled de 1994 à 2000.

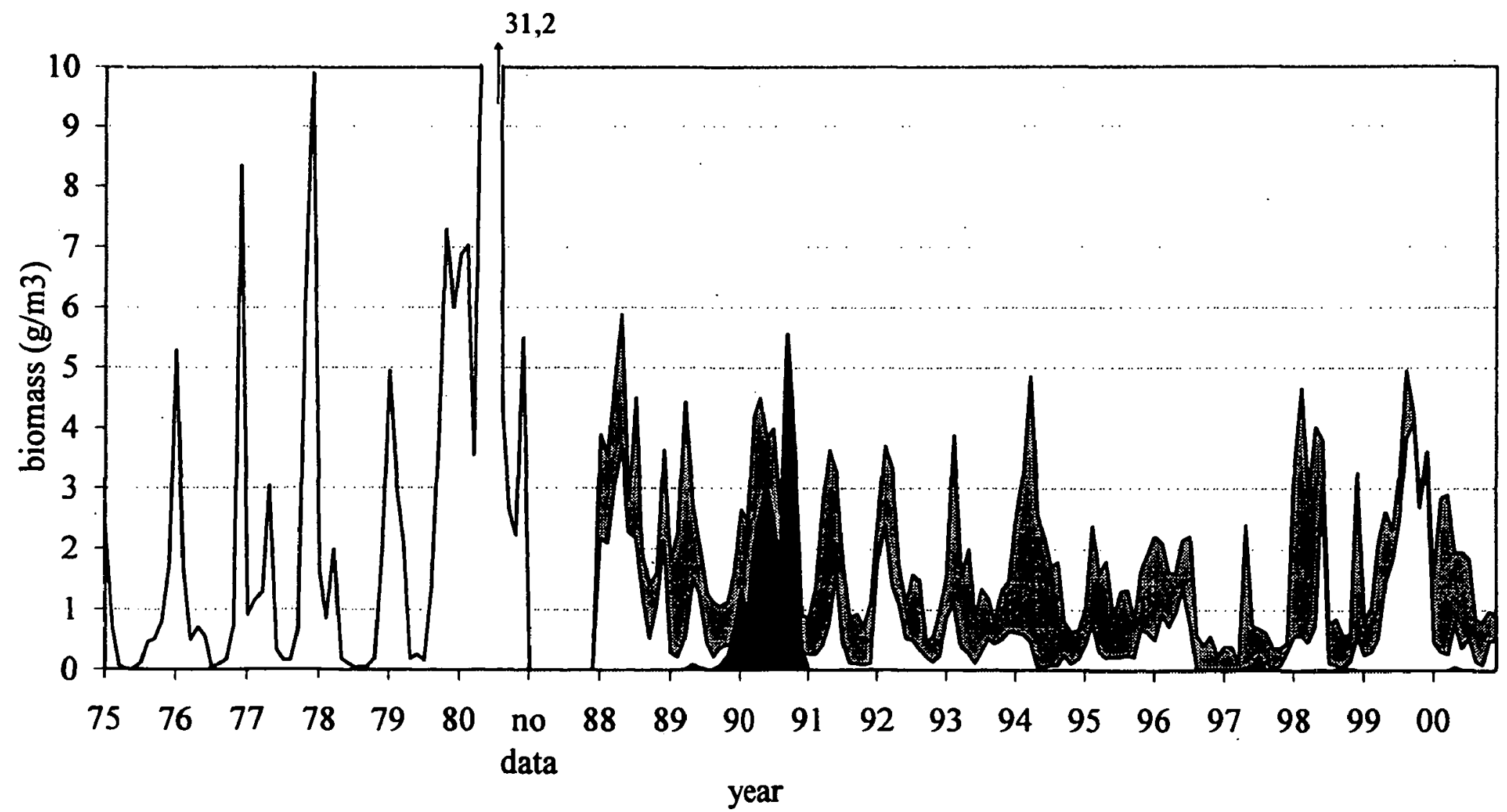

total phytoplankton

Aphanizomenon spp.

Fig. 19. Occurrence of different cyanophyte species in comparison to the combined mass of other phytoplankton groups in Lake Bled from 1975 to 2000.

Fig. 19. Présence de différentes espèces de cyanophytes et comparaison avec la biomasse des autres groupes du phytoplankton de 1975 à 2000 dans le lac Bled. 


\section{Acknowledgments}

The authors thanks are due to Jiri Komárek, Ceské Budejovice, for his valuable comments, and Hedy Kling, Winnipeg, for critically reading the manuscript and linguistic advice ; to Petr Marvan, Brno, for correctig the Latin diagnosis and René Le Cohu, Toulouse, for the French, translation. This study is part of the Slovene National Water-Quality Monitoring Programme (S.R.) and the VEGA project No. 2/1070/21 (F.H.) supported by the Slovak Academy of Sciences.

\section{References}

Anagnostidis K., Economou-Amilli A. \& Tafas T. 1988. - Aphanizomenon sp. from Lake Trichonis, Hellas (Greece) - a taxonomical consideration in relation to morphological and ecological parameters. Arch. Hydrobiol. Suppl. 80. Algol. Studies, 50-53 : 529-543.

Anonymus 1982. - Eutrophication of waters. Monitoring, Assesment and Control. OECD. Paris.

Bercic-Urbanc O. 1995. - Aquatic vegetation in two pre-alpine lakes of different trophic levels (Lake Bled and Lake Bohinj) : vegetation development from the aspect of bioindication. Acta bot. Gallica, 142 : 563-570.

Geitler L. 1932-1932. - Cyanophyceae. Rabenhorst's Kryptogamenflora von Deutschland. Österreich und der Schweiz. Akad. Verlagsges, Leipzig, $14: 1-1196$.

Hansgirg A. 1890. - Über neue Süsswasser und Meeres Algen und Bacterien. Stzber. D. Böhm. Gesellsch. d. Wiss. 1. Praha.

Hindák F. 1992. - Several interesting planktic cyanophytes. Arch. Hydrobiol. Suppl. 94, Algol. Studies, 66 : 1-15.

Hindák F. 2000. - Morphological variation of four planktic nostocalean cyanophytes - members of the genus Aphanizomenon or Anabaena? Hydrobiologia, 438 : 107-116.

Hindák F. \& Moustaka M. 1988. - Planktic cyanophytes of lake Volvi. Greece. Arch. Hydrobiol. Suppl. 80, Algol. Studies, 50-53 : 497-528.

Hollerbach M.M., Kosinskaja E.K. \& Poljanskij V.I. 1953. - Sinezelenye vodorosli. Opred. presnovodn. vodor. SSSR. Sov. Nauka, Moskva, 2 : 1-652.

Horecká M. \& Komárek J. 1979. - Taxonomic position of three planktonic blue-green algae from the genera Aphanizomenon and Cylindrospermopsis. Preslia, 51 : 289-312.

Huber-Pestalozzi G. 1938. - Das Phytoplankton des Süsswassers. 1. Teil : Allgemeiner Teil. Blaualgen. Bakterien. Pilze. In Thienemann. A. (ed.). Die Binnengewässer, 16/1 : 1-342.

International standard ISO $10260: 1992$ (E). - Water quality Measurement of biochemical parameters - Spectrometric determination of the chlorophyll- $a$ concentration.

Kellar P.E., Paulson S.A. \& Paulson L.J. 1980. - Methods for biological, chemical and physical analyses in reservoirs. Tech. rep. 5, Lake Mead Limnological Res. Center, Univ. Nevada, Las Vegas, $234 \mathrm{p}$.
Kling H.J., Findlay D.L. \& Komárek J. 1994. - Aphanizomenon schindleri sp. nov : a new nostocacean cyanoprokaryote from the Experimental Lakes Area, northwestern Ontario. Can J. Fish. Aquat. Sci., 51 : 2367-2273.

Komárek J. 1958. - Die taxonomische Revision der planktischen Blaualgen der Tschechoslowakei. pp. 10-206. In Komárek J. \& Ettl H. (eds). Algologische Studien. Praha, Nakl. CSAV : $358 \mathrm{p}$.

Komárek J. 1996. - Klic k urcovani vodnich kvetu sinic v Ceské republice. pp. 22-85. In Marsalek B., Kersner V. \& Marvan P. (eds), Vodni kvety sinic. Nadatio Flos-aquae, Bmo : 142 p.

Komárek J. \& Anagnostidis K. 1989. - Modern approach to the classification system of Cyanophytes 4 - Nostocales. Arch. Hydrobiol. Suppl. 82. 3, Algol. Studies, 56 : 247-345.

Komárek J. \& Kovacik L'. 1989. — Trichome structure of four Aphanizomenon taxa (Cyanophyceae) from Czechoslovakia with notes on the taxonomy and delimitation of the genus. Pl. Syst. Evol., 164 : 47-64.

Komárková-Legnerová J. \& Mátyás K. 1995. - Aphanizomenon hungaricum, a new species from the Kis Balaton Protecting System, Hungary. Arch. Protistenkd., 145 : 24-28.

Kondrateva N.V. 1968. - Sino-zeleni vodorosti - Cyanophyta, chastina 2. Klas Gormogonievi Hormogoniophyceae. Vizn. Prisnovodnich Vodor. Ukr. RSR, Naukova dumka Kiiv, 1/2 : 1-524.

Rejic M. \& Sketelj J. 1962. - Preliminarno porocilo o raziskavah Blejskega jezera. Gradb. Vest. Ljubljana, 41 : 61-64.

Reynolds C.S. 1984. - The ecology of freshwater phytoplankton. Cambridge University Press, Cambridge : $384 \mathrm{p}$.

Sournia A. 1978. - Phytoplankton manual. UNESCO.

Standard Methods for the Examination of Water and Wastewater. 1985. $-16^{\text {th }}$ edition. American Public Health Association. New York.

Standard Methods for the Examination of Water and Wastewater. 1992. $-18^{\text {th }}$ edition. American Public Health Association. New York.

Starmach K. 1966. - Cyanophyta - sinice. Glaucophyta - glaukofity. Flora slodkowodna Polski. PWN Warszawa, 2: 1-808.

Thompson A.S., Rhodes J.C. \& Petterman I. 1988. - Culture collection of algae and protozoa. Catalogue of Strains. Natural Environmental Research Council.

Vrhovsek D. \& Kosi G. 1981. - Comparison of Lake Bled Condition with a help of indicator species of algae at different periods from 1890. Biol. Vest., 29/2: 137-156.

Vrhovsek D., Kosi G. \& Zupan M. 1982. - The effect on water chemistry and phytoplankton of artificial inflow of the River Radovna into Lake Bled. Hydrobiologia, 96 : 225-242.

Watanabe M. 1991. - Studies on the planktonic blue-green algae 3. Some Aphanizomenon species in Hokkaido. Northern Japan. Bull. Nat. Sci. Mus. Tokyo. Ser. B. $17 / 4$ : 141-150.

Wetzel G.R. \& Likens G.E. 1990. — Limnological Analyses. Springer - Verlag. 2nd Ed. 